\title{
Total Digestible Nutrient of Diet Containing PUFA- Concentrate Supplemented with Yeast and Curcuma xanthorrhiza Roxb for Dairy Goat
}

\author{
Endang Sulistyowati ${ }^{*}$, Asep Sudarman², Komang G. Wiryawan ${ }^{2}$, and Toto Toharmat ${ }^{2}$ \\ ${ }^{1}$ Department of Animal Science, Faculty of Agriculture, University of Bengkulu, \\ Jl. Raya WR. Supratman, Bengkulu 38371, Indonesia \\ ${ }^{2}$ Department of Nutrition and Feed Science, Faculty of Animal Science, Bogor Agricultural \\ University, \\ Jl. Agatis, Kampus IPB Darmaga Bogor 16680, Indonesia \\ *Email: ensulistyowati@yahoo.com
}

\begin{abstract}
This research was designed to evaluate nutrient digestibility, mentioned as Total Digestible Nutrient of diet containing PUFA (polyunsaturated fatty acid) - concentrate supplemented with yeast and Curcuma xanthorrhiza Roxb for dairy goat. Twenty Ettawah crossbred goat in late lactation were allocated into 6 treatments in randomized block design. The treatments were PD0: PUFA-diet with no supplement, PDA: with Asifit, PDY: with $0.5 \%$ yeast, PDC: with $2 \%$ curcuma, and PDM: with $0.5 \%$ yeast $+2 \%$ curcuma. The PUFA-diet contained of $80 \%$ PUFA- concentrate as basic diet and $20 \%$ Pennisetum purpureum. While the PUFA sources were roasted ground corn and roasted soybean meal, and corn oil. Results showed that intakes of DM, OM, CP, CF, NFE, ADF, and GE were not affected significantly by dietary treatments. However, EE and NDF among treatments were different significantly $(\mathrm{P}<0.05)$, whereas $\mathrm{Ca}$ and $\mathrm{P}$ were different very significantly $(\mathrm{P}<0.01)$. High nutrient contents (DM, OM, CP, EE, CF, NDF, and GE) were found in feces of the goat with curcuma diet (PDC), consequently showed the opposite effects by giving the lowest digestibility $(\mathrm{P}<0.05$ or $\mathrm{P}<0.01)$ of these nutrients. Total digestible nutrient (TDN) of PDY and PDM were markedly higher (79.89\% and $79.37 \%$, respectively) than that in other diets, such as being the lowest was in PDC $(69.94 \%)$. This suggested that the yeast concentration of $1.810^{8} \mathrm{cfu} / \mathrm{d}$, given singly or in combination with $2 \%$ Curcuma could be considered as the right level for improving nutrient digestibility in the late lactation goat in our study.
\end{abstract}

Keywords: curcuma, dairy goat, PUFA-diet, TDN, yeast

\begin{abstract}
ABSTRAK
Penelitian ini didisain untuk mengevaluasi kecernaan nutrisi, dinyatakan dalam TDN, dari ransum yang mengandung PUFA konsentrat yang disuplementasi yeast dan Curcuma xanthorrhiza Roxb pada kambing perah. Dua puluh ekor kambing Peranakan Ettawah (PE) pada fase laktasi akhir dialokasikan kedalam 6 perlakuan dengan Rancangan Acak Kelompok. Perlakuan tersebut adalah: PD0: PUFA-diet tanpa suplemen, PDA: dengan Asifit, PDY: dengan 0,5\% yeast, PDC: dengan $2 \%$ curcuma, dan PDM: dengan 0,5\% yeast + 2\% curcuma. Ransum- PUFA terdiri atas $80 \%$ PUFA- konsentrat sebagai ransum dasar dan $20 \%$ rumput gajah. Sumber PUFA terdiri atas jagung giling sangrai, tepung kedelai sangrai, dan minyak jagung. Hasil menunjukkan bahwa konsumsi DM, OM, CP, CF, NFE, ADF, dan GE tidak terpengaruh oleh perlakuan. Namun, EE dan NDF antarperlakuan berbeda signifikan $(\mathrm{P}<0.05)$, sedang $\mathrm{Ca}$ dan $\mathrm{P}$ berbeda sangat signifikan $(\mathrm{P}<0.01)$. Kandungan nutrisi yang tinggi (DM, OM, CP, EE, CF, NDF, and GE) ditemukan di feces pada kambing dengan perlakuan Curcuma (PDC), konsekuensinya adalah kecernaan nutrisinya secara signifikan $(\mathrm{P}<0.05)$ atau sangat signifikan $(\mathrm{P}<0.01)$ terendah. Total digestible nutrient (TDN) dari PDY dan PDM secara signifikan tinggi (79,89\% dan 79,37\%) disbanding ransum lainnya, terendah pada PDC (69,94\%). Hal ini menunjukkan bahwa yeast atau ragi dengan konsentrasi $1,810^{8} \mathrm{cfu} / \mathrm{d}$ baik disuplementasikan tunggal atau dikombinasi dengan $2 \%$ Curcuma dapat dikatakan sebagai kandungan yang tepat untuk memperbaiki kecernaan nutrisi pada kambing perah dengan laktasi akhir pada penelitian ini.
\end{abstract}

Kata kunci: curcuma, kambing perah, PUFA-diet, TDN, yeast

\section{INTRODUCTION}

Yeast supplementation in ruminants has been reported with variable results, depending upon the nature of diets and yeast as well as the lactation stage. Wallace et al. (1994) described some increases in microbes population, fiber digestibility, protein microbes, feed intake, nutrient supply into digestive track, eventually improved production performance. Positive effects of yeast were found on rumen volatile fatty acid, dry matter intake, crude protein, and organic matter digestibility; however the impaired 
effect on decreasing lactic acid could be overcomed by increasing concentrate in diet (Desnoyers et al., 2009). Improved nutrient digestibility and quantatively increased fat and energy milk were showed by yeast supplementation (Saccharomyces cereviseae CNCM 1-1077, $\left.1.210^{10} \mathrm{cfu} / \mathrm{d}\right)$ in Holstein cows (Bagheri et al., 2009), increased milk yield with $20 \mathrm{~g} / \mathrm{d}$ in Holstein cows (Sulistyowati et al., 2010), and improved milk yield and milk fat with 50g RumiSacc in Holstein cows (Yalcin et al., 2011).

Medicinal herbs have been applied to improve health status and production performance as they have galactogouge property and digestive process as reported by Mirzaei and Prasad (2011) that low dose $(125 \mathrm{mg} / \mathrm{kg} \mathrm{BW})$ of polyherbal increased milk yield and kids performance. Curcuma xanthorrhiza Roxb powder $\quad(15 \mathrm{~g} / \mathrm{kg}$ concentrate) was optimal in improving milk yield and milk composition in Holstein cows (Sulistyowati et al., 2011); whereas Sinaga et al. (2011) reported that curcumin extract (160 ppm) of $C$. domestica improved energy digestibility of ration, decreased rate of passage such that the retention time was longer and increased absorption that finally improved body weight in pig. Curcumin was described to increase bile and lipase that will improve fat digestibility and decrease cholesterol; beside, as anti pathogen microbes, improve nutrient absorption then improve production performance (Bauwman et al., 1983). Therefore, it would be beneficial to apply either yeast or curcuma or in combination in concentrate containing PUFA (polyunsaturated fatty acid) sources to evaluate nutrient digestibility and milk yield in late lactation dairy goat.

\section{MATERIALS AND METHOD}

\section{Yeast, Curcuma, PUFA-diet, and Application}

Yeast and Curcuma powder supplements and PUFA- diets were prepared as reported in Sulistyowati et al. (2013) and Sulistyowati et al. (2014). The diet contained of $18.42 \%$ rice brand, $15.79 \%$ ground corn (half roasted), $7.89 \%$ soybean meal (all roasted), $7.89 \%$ cassava meal, $27.49 \%$ soybean- byproduct, $2.11 \%$ corn oil, $0.53 \%$ mineral mix, and $19.88 \%$ king grass (Panicum maximum).
Treatments were based on the basic diet containing PUFA- concentrate and soybean by- product as PUFA- diet (PD) without supplements designated as (PD0), added with 3 tablets/dairy goat of Asifit (PDA), $0.5 \%$ or $5 \mathrm{~g}$ yeast (PDY), $2 \%$ or $20 \mathrm{~g}$ curcuma powder (PDC), 5g yeast and 20g curcuma powder (PDM). Asifit, a tablet of food supplement for a woman in lactation, contains of $114 \mathrm{mg}$ Sauropus androgynus, $20 \mu \mathrm{g}$ vitamin B12, 15 $\mathrm{mg}$ vitamin $\mathrm{B} 6,2.5 \mathrm{mg}$ vitamin $\mathrm{B} 2$, and $10 \mathrm{mg}$ vitamin B1 (produced commercially by Kimia Farma, Indonesia).

The study was conducted according to Complete Block design $5 \times 4$, with 14 days for adaptation, 21 days for sampling and data recording, and 21 days post treatment was also for data recording. The dairy goats used were PE (Ettawa Crossed), blocked according to their milk production. During the experiment, each of 20 goats was kept individually, provided with feed twice of $0.5 \mathrm{~kg}$ PUFA- concentrate and $1 \mathrm{~kg}$ fresh soybean by-product at 07.00 am and $03.00 \mathrm{pm}$. Forage was given $2 \mathrm{~kg} / \mathrm{goat}$ at afternoon feeding. Orts of concentrate and forage were weighed in the next morning. Milk yield was recorded daily before, during, and after treatment. Sampling of individual milk was collected from two consecutive milkings of the afternoon and the next morning of the last day of collection period. Voluntary feed intake was recorded throughout the experiment, but only the last 7 days were considered for data analysis as they were at the same days for feces collection.

\section{Chemical and Statistical Analysis}

The diets (concentrate and forage) and feces were oven dried $\left(60^{\circ} \mathrm{C}\right.$ for 24 hours), ground finely ( $1 \mathrm{~mm}$ sieved size) analyzed for dry matter $(\mathrm{DM})$, organic matter $(\mathrm{OM})$, crude protein $(\mathrm{CP})$ by Kjeldhal method, and ether extract (EE) by Soxhlet method (AOAC 1990). Cell wall contents, neutral detergent fiber (NDF) and acid detergent fiber (ADF) were determined according to Van Soest et al. (1991). Calcium (Ca, $422.7 \mathrm{~nm}$ ) was determined by using Atomic Absorbance AA7000 Shimadzu Co. Serial no A 30664700345. Phosphor (P, $660 \mathrm{~nm}$ ) was prepared by wet ashing method and quantified by using Spectrophotometer UV-200 RS UV VIS LW Scientific according to procedure of Dairy Nutrition Laboratory- IPB. 
Data were tabulated using Microsoft Office Excel 2003. Analysis of variance with any differences detected by Duncan Multiple Range Test (DMRT) in significances of $\mathrm{P}<0.05$ and $\mathrm{P}<0.01$ according to Lentner and Bishop (1986).

\section{RESULTS AND DISCUSSION}

\section{Nutrient intakes}

Intakes of dry matter (DM), organic matter $(\mathrm{OM})$, crude protein $(\mathrm{CP})$, crude fiber (CF), nitrogen free extract (NFE), acid detergent fiber (ADF), and gross energy (GE) were not affected significantly by dietary treatments (Table 1). However, ether extract (EE) and neutral detergent fiber (NDF) among treatments were different significantly $(\mathrm{P}<0.05)$, whereas $\mathrm{Ca}$ and $\mathrm{P}$ were different very significantly $(\mathrm{P}<0.01)$. The DMI which were around $2.5 \%$ (PDA) to $2.8 \%$ (PDY) considered lower compared to the dry matter requirement for lactating dairy goat $3.2 \%$ to $4.5 \%$ (NRC, 1981). This fact may lead to the low milk production of all treatments, besides, the goats were in late lactation phase (Table 2). However, these two treatments (Asifit and yeast) showed quantitatively higher milk production, describing that $S$. androgynus plus B Vitamin did stimulate lactation hormone, while, S. cerviseae improved rumen metabolism in such a way that nutrient intakes would be utilized efficiently to increase milk production.

Response on intakes of yeast supplementation have been summarized as variable (Desnoyers et al., 2009). There was no effects of dietary live yeast alone $\left(1.210^{10}\right.$ $\mathrm{cfu} / \mathrm{d})$ or in combination with mannanoligosaccharide $(32 \mathrm{~g} / \mathrm{d})$ on dry matter intake and milk yield of lactating Holstein (Bagheri et al., 2009). In contrast, the result of yeast diet (PDY) intakes in this present study tended to be the highest in dry matter and organic matters, crude fiber, NFE, and NDF. This has been supported by its high milk yield, $4 \%$ FCM, and protein content (Sulistyowati et al., 2014). The supplementation of yeast, rich in Saccharomyces cereviseae, B vitamins, and amino acids, has been reported to stabilize ruminal fermentation, increased rumen $\mathrm{pH}$, and altered VFA levels (William et al., 1991) that eventually improve milk production and milk component.

Table 1. Effects of feedingPUFA-diets supplemented with asifit, yeast and $\quad$ C. xanthorrhiza Roxb on nutrient intakes of dairy goats

\begin{tabular}{lccccccc}
\hline Intakes (g/d) & PD0 & PDA & PDY & PDC & PDM & SEM & P \\
\hline Dry matter & 1228.95 & 1128.92 & 1273.07 & 1153.94 & 1239.94 & 60.88 & NS \\
Organic matter & 1114.60 & 1023.76 & 1159.02 & 1054.85 & 1127.59 & 55.29 & NS \\
Crude protein & 181.74 & 166.89 & 177.25 & 172.49 & 181.52 & 6.33 & NS \\
Ether extract & $79.94^{\mathrm{ab}}$ & $73.28^{\mathrm{a}}$ & $86.67^{\mathrm{bc}}$ & $80.90^{\mathrm{abc}}$ & $91.06^{\mathrm{c}}$ & 6.79 & $*$ \\
Crude fiber & 221.08 & 203.72 & 243.23 & 244.02 & 231.51 & 16.85 & $\mathrm{NS}$ \\
NDF & $914.70^{\mathrm{ab}}$ & $840.78^{\mathrm{a}}$ & $1109.74^{\mathrm{c}}$ & $978.10^{\mathrm{bc}}$ & $992.59^{\mathrm{bc}}$ & 99.77 & $*$ \\
ADF & 516.91 & 476.58 & 546.55 & 442.55 & 516.27 & 40.51 & $\mathrm{NS}$ \\
$\mathrm{Ca}$ & $7.78^{\mathrm{a}}$ & $7.15^{\mathrm{a}}$ & $13.55^{\mathrm{c}}$ & $11.03^{\mathrm{b}}$ & $9.99^{\mathrm{b}}$ & 2.58 & $* *$ \\
P & $6.32 \mathrm{~b}^{\mathrm{c}}$ & $5.81^{\mathrm{b}}$ & $7.13^{\mathrm{c}}$ & $6.74^{\mathrm{bc}}$ & $4.67^{\mathrm{a}}$ & 0.95 & $* *$ \\
\hline
\end{tabular}

PUFA- concentrate and soybean by- product without supplements designated as (PD0), added with 3 tablets/dairy goat of ASIFIT (PDA), $0.5 \%$ or $5 \mathrm{~g}$ yeast (PDY), $2 \%$ or $20 \mathrm{~g}$ curcuma powder (PDC), mix of $5 \mathrm{~g}$ yeast and $20 \mathrm{~g}$ curcuma powder $(\mathrm{PDM}) . *(\mathrm{P}<0.05) ; * *(\mathrm{P}<0.01)$; NS: not significant.

\section{Nutrient digestibility and Total Digestible Nutrient}

Nutrients digestibility of dry matter, organic matter, crude protein, ether extract, crude fiber, NFE, NDF, ADF, gross energy, and TDN were showed statistically the highest $(\mathrm{P}<0.05)$ in yeast diet (PDY) and in the mix diet (PDM); as well as for $\mathrm{Ca}$ and $\mathrm{P}$ were detected the highest in this diet (Table 2). Our data showed that improved nutrient digestibility as a result of increased nutrient intake that followed by increased milk yield as an average of pre, treatment, and post treatment in PDM $(392.00 \mathrm{ml} / \mathrm{d})$ that was with good persistency after the treatment.

Dietary yeast supplement will stimulate rumen microbes growth, increased the use of $\mathrm{N}$ - ammonia for protein rumen 
microbes, and increased digestibility of fiber, increased feed intakes and nutrient supply to the gut and improved blood metabolites, eventually increased production (Wallace $e t$ al., 1994). Supplementation of yeast only or in combination in this treatment did

affect the goats reflecting the nature of diets, phase of lactation, feeding regime, yeast type and level, forage type and level, and environment as stated by Yalçın et al. (2011).

In terms of tannin $(0.49 \%)$ and curcumin $(0.12 \%)$ contents in the rations as reported separately (Sulistyowati et al., 2013), yeast only (PDY), curcuma only (PDC), or in combination with curcuma (PDM) seemed to affect intakes and digestibility of ether extract and NDF higher $(\mathrm{P}<0.05)$ than that in basal diet or Asifit diet. These supported the result of tannin and saponin sources from Yucca schidigera that increased digestibility of NDF, besides increased digestibility of DM, GE, CP, and ADF (Holtshausen et al., 2009).

Total digestible nutrient (TDN) of PDY and PDM were markedly higher $(79.89 \%$ and $79.37 \%$ ), respectively than that in other diets, such as being the lowest was in PDC $(69.94 \%)$. Meaning that, yeast only or in combination with curcuma is more efficient in digesting nutrient than that with curcuma only.

Table 2. Effects of feding PUFA-diets supplemented with asifit, yeast and $\quad$ C. xanthorrhiza Roxb on nutrient digestibility of dairy goats

\begin{tabular}{lccccccc}
\hline $\begin{array}{l}\text { Digestibility } \\
(\%)\end{array}$ & PD0 & PDA & PDY & PDC & PDM & SEM & P \\
\hline Dry matter & $77.09^{\mathrm{ab}}$ & $78.66^{\mathrm{abc}}$ & $84.82^{\mathrm{c}}$ & $73.77^{\mathrm{a}}$ & $83.49^{\mathrm{bc}}$ & 4.57 & $*$ \\
Organic matter & $76.89^{\mathrm{ab}}$ & $78.46^{\mathrm{abc}}$ & $84.53^{\mathrm{c}}$ & $73.31^{\mathrm{a}}$ & $83.26^{\mathrm{bc}}$ & 4.62 & $*$ \\
Crude protein & $79.46^{\mathrm{b}}$ & $81.00^{\mathrm{b}}$ & $85.76^{\mathrm{b}}$ & $73.80^{\mathrm{ab}}$ & $84.96^{\mathrm{ab}}$ & 4.81 & $* *$ \\
Ether extract & $83.30^{\mathrm{a}}$ & $89.40^{\mathrm{b}}$ & $92.13^{\mathrm{b}}$ & $81.81^{\mathrm{a}}$ & $92.05^{\mathrm{b}}$ & 4.88 & $* *$ \\
Crude fiber & $62.04^{\mathrm{a}}$ & $64.31^{\mathrm{a}}$ & $76.64^{\mathrm{b}}$ & $63.06^{\mathrm{a}}$ & $72.25^{\mathrm{ab}}$ & 6.43 & $*$ \\
NFE & $82.82^{\mathrm{ab}}$ & $83.07^{\mathrm{ab}}$ & $87.64^{\mathrm{b}}$ & $78.24^{\mathrm{a}}$ & $87.00^{\mathrm{b}}$ & 3.79 & $* *$ \\
NDF & $71.41^{\mathrm{a}}$ & $73.63^{\mathrm{a}}$ & $85.99^{\mathrm{b}}$ & $74.83^{\mathrm{a}}$ & $83.48^{\mathrm{b}}$ & 6.45 & $* *$ \\
ADF & $56.53^{\mathrm{a}}$ & $60.60^{\mathrm{ab}}$ & $75.25^{\mathrm{c}}$ & $56.31^{\mathrm{a}}$ & $72.98^{\mathrm{bc}}$ & 9.13 & $*$ \\
Ca & $50.45^{\mathrm{a}}$ & $70.04^{\mathrm{b}}$ & $85.37^{\mathrm{c}}$ & $74.50^{\mathrm{b}}$ & $87.83^{\mathrm{c}}$ & 14.92 & $* *$ \\
P & $68.76^{\mathrm{a}}$ & $82.42^{\mathrm{b}}$ & $83.79^{\mathrm{b}}$ & $80.52^{\mathrm{b}}$ & $86.03^{\mathrm{b}}$ & 6.76 & $* *$ \\
TDN & $72.42^{\mathrm{a}}$ & $74.07^{\mathrm{ab}}$ & $79.89^{\mathrm{b}}$ & $69.94^{\mathrm{a}}$ & $79.37^{\mathrm{b}}$ & 4.36 & $* *$ \\
Milk yield & 336.33 & 538.67 & 522.33 & 322.33 & 392.00 & 102.29 & \\
(ml/d) & & & & & & &
\end{tabular}

PUFA- concentrate and soybean by- product without supplements designated as (PD0), added with 3 tablets/dairy goat of ASIFIT (PDA), $0.5 \%$ or $5 \mathrm{~g}$ yeast (PDY), $2 \%$ or $20 \mathrm{~g}$ curcuma powder (PDC), mix of $5 \mathrm{~g}$ yeast and $20 \mathrm{~g}$ curcuma powder $(\mathrm{PDM})$. Effects significantly different $(\mathrm{P}<0.05)$ or very significantly different $(\mathrm{P}<0.01)$; NS: not significant.

To correlate with, the high nutrient contents (DM, OM, CP, EE, CF, NDF, and $\mathrm{GE)}$ were found in feces of the goat with curcuma diet (PDC), consequently showed the opposite effects by giving the lowest digestibility $(\mathrm{P}<0.05$ or $\mathrm{P}<0.01)$ of these nutrients. This might be as the result of the nature of curcuma powder given on top of the concentrate that would taste bitter and smell strong that the goat avoided or by- passing it in such a way that the nutrient content in the diet would be decreasingly digested. In contrast, the most nutrient digested both in yeast diet (PDY) and mix diet (PDM) were significantly higher $(\mathrm{P}<0.01)$, suggesting that yeast fermented better either singly or in combination with curcuma. Moreover, both treatments produced some good amounts of milk, $522.33 \mathrm{~g} / \mathrm{d}$ and $392.00 \mathrm{~g} / \mathrm{d}$, respectively. These diets were showing higher digestibilities in dry matter, crude fiber, and NDF compared to that of $1.210^{10} \mathrm{cfu} / \mathrm{d}$ yeast diet in Holstein dairy cows as reported by Bagheri et al. (2009). This suggested that the yeast concentration of $1.8 \quad 10^{8} \mathrm{cfu} / \mathrm{d}$ could be considered as the right level for improving nutrient digestibility in the late lactation goat in our study. 


\section{CONCLUSION}

Diets that contained PUFA- concentrate supplemented with $0.5 \%$ yeast singly or in combination with $2 \%$ Curcuma xanthorrhiza Roxb showed the highest Total Digestible Nutrient $(79.89 \%$ and $79.37 \%$, respectively) with good amounts of milk in late lactation dairy goat.

\section{ACKNOWLEDGEMENTS}

Authors would like to thank Directorate General for Higher Education (DGHE) for funding this project through HIBAH STRANAS - IPB with contract no:134/SP2H/PL/DIT.LITABMAS/V/2013, signed on May 13, 2013.

\section{REFERENCES}

Bagheri, M., G.R. Ghorbani, H.R. Rahmani, M. Khorvash, N. Nili, and K.H. Südekum. 2009. Effect of live yeast and mannan-oligosaccharides on performance of early-lactation holstein dairy cows. Asian-Aust J Anim Sci. Vol. 22, No. $6: 812-818$.

Bawman, J.C. 1983. Concerning the effect of chelidonium, curcuma, absinth, and milkhistle on billiary and pancreatic secretion in hepathopathy. Med Monalsschriff 29: 173- 180.

Desnoyers, M., S. Giger-Reverdin, G. Bertin, C. Duvaux-Ponter, and D. Sauvant. 2009. Meta-analysis of the influence of Saccharomyces cerevisiae supplementation on ruminal parameters and milk production of ruminants. $\mathrm{J}$ Dairy Sci. 92 :1620-1632.

Holtshausen, L., A. V. Chaves, K. A. Beauchemin, S. M. McGinn, T. A. McAllister, N. E. Odongo, P. R. Cheeke, and C. Benchaar. 2009. Feeding saponin- containing Yucca schidigera and Quillaja saponaria to decrease enteric methane production in dairy cows. J. Dairy Sci. 92: 28092821.

Lentner M, Bishop T. 1986. Experimental Design and Analysis. Valley Book Co. VA.

Mirzaei, F. and S. Prasad. 2011. Influence of dietary phytoadditive as polyherbal combination on performance of does and respective litters in cross bred dairy goats. Asian- Aust J Anim Sci. 24 (10): 1386-1392.

[NRC]. National Research Council. 1981. National Research Council. Nutrient Requirements of Goats: Angora, Dairy, and Meat Goats in Temperate and Tropical Countries. National Academy Press. Washington, DC (US).

Sinaga, S, D.T.H. Sihombing, M. Bintang, and Kartiarso. 2011. The effect of ration containing curcumin (extract turmeric/Curcuma domestica) in pigs rations to replace antibiotic synthetic as growth promoter). Forum Pascasarjana Vol. 33 No. 2: 123-131.

Sulistyowati, E., I. Badarina, and E. Soetrisno. 2010. Supplementation of Starbio probiotic and yeast on milk production and nutrient digestibility of lactating Holstein cows fed a ration containing cassava meal. J Dairy Sci. 93. E- Suppl. 1: 860.

Sulistyowati, E., U. Santoso, and I. Badarina. 2011. Supplementation of concentrate with different levels of temulawak (Curcuma xanthorriza Roxb) on milk production of lactating Frisien Holland cows. Proceedings: The $2^{\text {nd }}$ International Symposium on Temulawak- the $40^{\text {th }}$ Meeting on National Working Group on Indonesian Medicinal Plant. ISBN: 978-979-251209-0. Pp: 116- 120.

Sulistyowati, E., A. Sudarman , K.G. Wiryawan, and T. Toharmat. 2013. Quality of milk fatty acid during late lactation in dairy goat fed on PUFAdiet supplemented with yeast and Curcuma xanthorrhiza Roxb. J.Indonesian Trop Anim Agric. 38(4): 247- 256.

Sulistyowati, E., A. Sudarman, K.G. Wiryawan, and T. Toharmat. 2014. Milk production of late lactation dairy goat fed PUFA-diet supplemented with yeast and $C$. xanthorrhiza Roxb. Proceeding the $2^{\text {nd }}$ Asian- Australasian Dairy Goat Conference. April 25- 272014. Bogor. Indonesia. Pp: 223-226.

Van Soest PJ, Robertson JB, and Lewis BA. 1991. Methods for dietary fiber, neutral detergent fiber and non starch polysaccharides in relation to animal nutrition. J Dairy Sci. 74:3583- 3592. 
Wallace, R.J. 1994. Ruminal microbiology, biotechnology, and ruminal nutrition: progress and problems. J Anim Sci. 72:2992-3003.

William, P.E.V., C.A.G. Tait, G.M. Innes, and C.J. Newbold. 1991. Effects of the inclusion of yeast culture (Saccharomyces cerevisiae plus growth medium) in the diet of dairy cows on milk yield and forage degradation and fermentation patterns in the rumen of steers. J Anim Sci. 69:3016- 3026.

Yalçın S, C. Pınar, O. Arif, Gürdal, C. Bağc, and O. Eltan. 2011. The nutritive value of live yeast culture (Saccharomyces cerevisiae) and its effect on milk yield, milk composition and some blood parameters of dairy cows. Asian- Aust J Anim Sci 24 (10): 1377-1385. 